\title{
Review : Perkembangan Teknologi Deteksi CoVID-19
}

\author{
Wetri Febrina ${ }^{1}$ \\ 1) Program Studi Teknik Industri, Sekolah Tinggi Teknologi Dumai \\ Jl. Utama Karya Bukit Batrem II, Dumai, Riau-Indonesia \\ Email: wetri.febrina@gmail.com
}

\begin{abstract}
ABSTRAK
Artikel ini merupakan review dari penelitian-penelitian internasional dalam kurun waktu 2020-2021 yang memuat perkembangan teknologi dalam pendeteksian CoVID-19. Sejak diketahui pertama kali di Wuhan tanggal 30 Desember 2020, CoVID-19 menjadi sumber masalah kesehatan di seluruh dunia hingga menjadi pandemik saat ini. Virus ini menyebar secara global, walau usaha pemblokiran Wuhan sudah dilakukan sejak awal virus ini terdeteksi. Yang membuat masalah ini menjadi berat adalah sedikitnya alas test yang efektif (POCT-Point of care testing) yang bisa secara tepat dan cepat mengidentifikasi pasien yang terinfeksi virus SARS-Cov-2 ini. Di Indonesia, kasus ini pertama kali dideteksi pada tanggal 2 Maret 2020 pada dua pasien di Jakarta, yang diikuti dengan penyebaran virus CoVID-19 yang begitu cepat dan meluas ke seluruh daerah di Indonesia. Tujuan dari artikel ini adalah untuk mengkaji perkembangan teknologi pendeteksian CoVID-19, mulai dari metode dan peralatan yang digunakan, sehingga bisa dibandingkan metode mana yang paling efektif dan paling efisien, baik dalam screening maupun dalam konfirmasi.
\end{abstract}

Kata kunci: CoVID-19, Detection Test of CoVID-19, Confirmation Test of CoVID-19, Screening Test of CoVID-19

\begin{abstract}
This article is a review of international research in the 2020-2021 period which includes technological developments in the detection of CoVID-19. Since it was first discovered in Wuhan on December 30, 2020, CoVID-19 has become a source of health problems worldwide until it has become the current pandemic. This virus has spread globally, although efforts to block Wuhan have been carried out since the beginning of this virus being detected. What makes this problem difficult is the lack of an effective test base (POCT-Point of care testing) that can accurately and quickly identify patients infected with the SARS-Cov-2 virus. In Indonesia, this case was first detected on March 2, 2020 in two patients in Jakarta, which was followed by the rapid spread of the CoVID-19 virus and spread to all regions in Indonesia. The purpose of this article is to examine the development of CoVID-19 detection technology, include all the methods and equipment used, so that it can be compared which method is the most effective and most efficient, both in screening and in confirmation.
\end{abstract}

Keywords: CoVID-19, Detection Test of CoVID-19, Confirmation Test of CoVID-19, Screening Test of CoVID-19 


\section{Pendahuluan}

Sejak diketahui pertama kali di Wuhan tanggal 30 Desember 2020, CoVID-19 menjadi sumber masalah kesehatan di seluruh dunia hingga menjadi pandemik saat ini. Virus ini menyebar secara global, walau usaha pemblokiran Wuhan sudah dilakukan sejak awal virus ini terdeteksi. Yang membuat masalah ini menjadi berat adalah sedikitnya alas test yang efektif (POCT-Point of care testing) yang bisa secara tepat dan cepat mengidentifikasi pasien yang terinfeksi virus SARS-Cov-2 ini. Sebagai tambahan, virus ini sangat menular, sehingga sebelum terdeteksi positif, pasien yang terinveksi akan dengan mudah menularkannya pada orang lain. (Y. Ji et al., 2020a)

Di Indonesia, kasus ini pertama kali dideteksi pada tanggal 2 Maret 2020 pada dua pasien di Jakarta, yang diikuti dengan penyebaran virus CoVID-19 yang begitu cepat dan meluas ke seluruh daerah di Indonesia.

Lebih lanjut, virus SARS-Cov2 ini muncul bertempatan dengan musim influenza, sehingga terjadi kunjungan serempak penderita flu dengan penderita CoVID-19, mempercepat penularan penyakit ini. Oleh karena itu alat pendeteksi yang tepat dan akurat amat sangat dibutuhkan, sehingga orang yang terinfeksi bisa diisolasi tepat waktu dan dilakukan pelacakan terhadap orang-orang yang berinteraksi dengan penderita. (Kucharski et al., 2020), (Hellewell et al., 2020)

\section{Jenis-jenis Virus Corona}

Tiga jenis corona virus yang menyerang manusia di abad ke 21, atau yang dikenal dengan SARS-CoV (Severe acute respiratory syndrome-Corona virus), yaitu : 1) SARS-Cov, 2) MERS-Cov dan 3) SARS-Cov-2. (Huang et.al, Zhu et.al)

1) SARS-CoV, terdeteksi tahun 2002 di Guandong, China. Virus ini menginfeksi delapan ribuan orang, dan 774 orang meninggal

2) MERS-CoV, terdeteksi tahun 2012 di Semenanjung Arab. Virus ini menginfeksi 2.500 orang dan 800-an orang meninggal dunia.

3) SARS-CoV2, terdeteksi bulan Desember 2019 DI Wuhan, China, dan pertama kali di sequenching dan diisolasi Januari 2020. Virus masih menjadi pandemic sampai sekarang dengan data per 26 September 2021 : Jumlah orang yang terinfeksi adalah sebanyak 231.631.760 dengan kematian 4.745.035 orang (data global). 4.028.013 dan kematian 141.467 orang (Indonesian case)

\section{Inang dan Perantara Virus Corona}

30 Januari 2020, WHO mengumumkan SARS-Cov-2 yang kemudian dikenal sebagai Covid-19 sebagai darurat kesehatan masyarakat yang menuntut perhatian dunia internasional. Baik SARS-Cov maupun SARS CoV2 dicurigai berasal dari kelelawar, yang lebih menyerupai inang bagi virus ini. MERS-CoV juga berasal dari kelelawar, tapi disebarkan melalui unta (Ge et.al, 2013, Hu et.al, 2017, Zhou et al, 2020). Sedangkan pada SARS Cov dan SARS-Cov-2, dicurigai virus ini ditransmisikan oleh musang sawit dan rakun, dari kelelawar ke manusia. Diprediksikan dimasa datang zoonotics transmission ini masih akan berlanjut (Anthony et.al, 2017, Zhou et al, 2020). Virus ini masuk ke sel melalui spike 
glycoprotein (bentuknya menyerupai paku/tonjolan pada permukaan virus). Spike ini memiliki dua tugas, yaitu mengikat pada sel reseptor dan menggabungkan virus dengan membrane sel

\section{Hasil dan Pembahasan}

\section{Struktur Partikel dan Genomik Virus Corona}

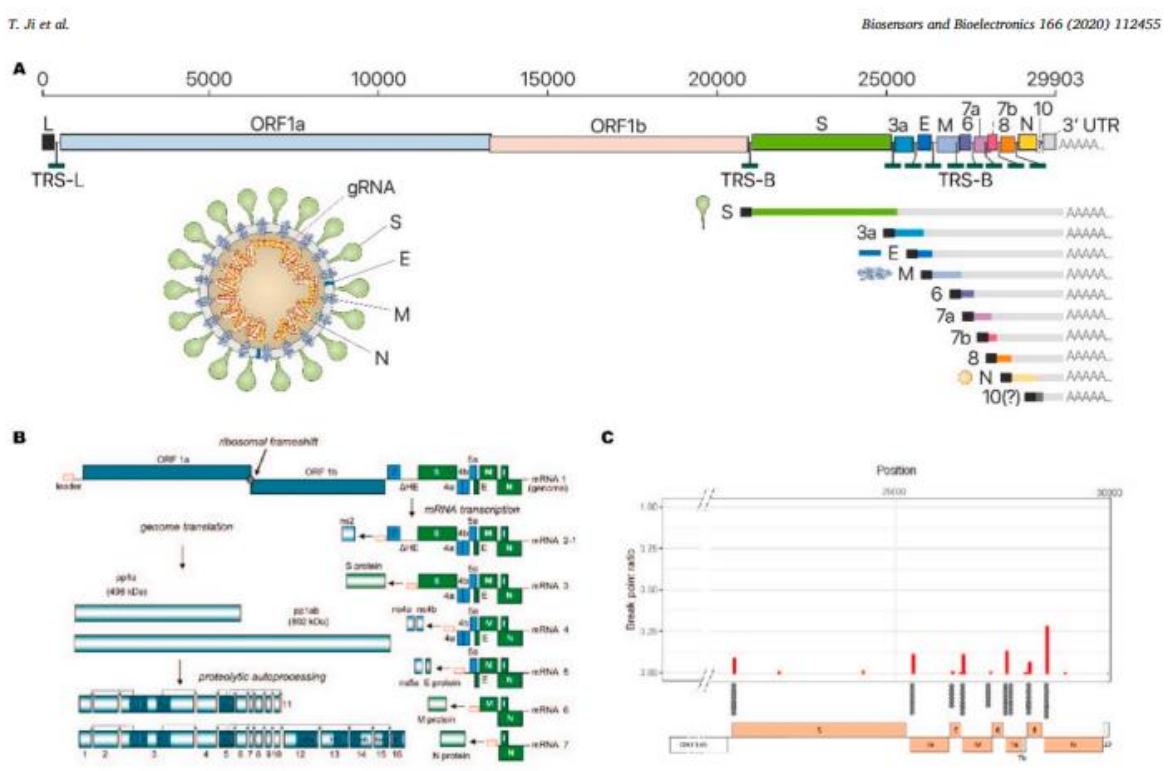

Gambar 1. Skema ilustrasi Genom Virus Corona, mRNA subgenomik kanonik dan struktur virus Sumber : (Ji et al., 2020)

SARS-CoV-2 termasuk ke dalam ordo Nidovirales, familia Coronaviridae, subfamilia Orthocoronavirinae, genus Betacoronavirus. Struktur genom RNA virus berbentuk melingkar (heliks), dibungkus oleh nukleoprotein (N) sehingga nukleokapsid ini berbentuk seperti tabung melingkar. Di sebelah luar nukleokapsid terdapat membran pembungkus (protein envelope, E) yang membungkus nukleokapsid. Walaupun nukleokapsid berbentuk tabung melingkar, envelope membungkus seluruh nukleokapsid dengan bentuk akhir partikel virus seperti bola. Diameter partikel coronavirus ini berkisar $80-220 \mathrm{~nm}$. Seperti coronavirus lainnya, partikel virus memiliki duri (spike) pada membran envelope di sebelah luarnya. Pada pengamatan di bawah mikroskop electron, struktur envelope dengan duridurinya tampak seperti mahkota (corona of the sun).

Pada partikel virus terdapat lima protein struktural penting dan beberapa protein asesoris. Nukleoprotein $(\mathrm{N})$ merupakan protein yang membungkus RNA virus. Matriks (M) merupakan glikoprotein yang menancap dalam envelop dan berperan dalam pembentukan intraseluler partikel virus. Spike (S) merupakan glikoprotein yang terdapat pada membran envelope partikel virus. $\mathrm{S}$ berperan penting untuk penempelan virus pada protein penerima (reseptor) sel inang yaitu angiotensin converting enzyme 2 (ACE2) dan memfasilitasi virus masuk ke dalam sel 
inangnya. Pada beberapa betacoronavirus terdapat hemagglutinin esterase (E) atau hem agglutinin-esterase. Selain itu terdapat protein yang penting untuk replikasi dan transkripsi virus yaitu RNA dependent RNA polymerase, RdRp. (Walls, 2020)

\section{Perkembangan Teknologi Screening Test dan Confirmation Test of CoVID-19}

Tata kelola kasus COVID-19 di Indonesia dilakukan sesuai arahan WHO. Tes serologis, yang sering disebut sebagai tes antibodi cepat, digunakan untuk tes skrining massal, sedangkan tes berbasis polymerase-chain-reaction (PCR) dilakukan untuk konfirmasi rutin kasus infeksi COVID-19. Uji PCR merupakan salah satu uji amplifikasi asam nukleat (NAAT) untuk mendeteksi RNA virus. Pengelolaan deteksi COVID-19 menimbulkan kontroversi di awal masa pandemi. Tampaknya kontroversi terjadi karena kesalahan persepsi tentang tes, serta kesalahpahaman yang disebabkan oleh perbedaan respons imun individu, dinamika virus dalam tubuh manusia, dan hasil klinis.

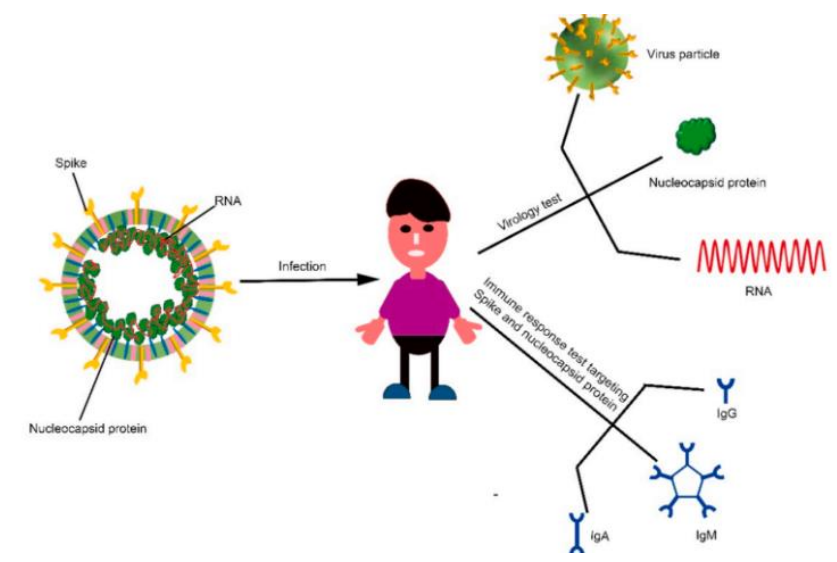

Gambar 2. Ilustrasi Deteksi Penderita CoVID-19

Sumber : Y. Ji et al., 2020b

Sejak virus menginfeksi hingga munculnya gejala penyakit pada pasien disebut periode inkubasi. Pada periode ini, SARS-CoV-2 berkembang biak, terutama pada sistem pernafasan. Periode inkubasi SARS-CoV-2 sangat bervariasi antar individu, berkisar 2 hari hingga 14 hari setelah paparan, dengan rata-rata sekitar 5 hari. RNA virus terdeteksi dalam pasien dengan gejala sedang (moderate) setidaknya 1 minggu setelah gejala penyakit terlihat, sedangkan untuk pasien dengan gejala berat lebih dari dua minggu. Penentuan periode inkubasi penting untuk pengawasan dan pengendalian penyakit infeksi walaupun data yang diperoleh seringkali merupakan perhitungan secara kasar. Untuk dapat ditularkan/disebarkan ke orang lain, diperlukan jumlah virus yang cukup. Perkiraan jumlah ini sulit ditentukan karena dipengaruhi oleh beberapa faktor (Li et al., 2020)

Penularan virus ini bisa terjadi sebelum individu terinfeksi menunjukkan gejala. Pada umumnya diperlukan waktu sekitar tiga hari sejak virus masuk dan berkembang biak dalam tubuh orang terinfeksi sampai mencapai jumlah yang siap ditularkan. Periode ini disebut sebagai periode laten. Setelah masa laten maka masa berikutnya merupakan masa seseorang dapat menularkan penyakit ini pada orang lain dengan sangat mudah (infeksious), selama sekitar 4 hari setelah masa laten. 
Di sisi lain, antibodi (IgM dan IgG) terhadap COVID-19 akan dibentuk oleh tubuh sebagai respon terhadap infeksi SARS-CoV-2. Pembentukan antibodi ini dimulai 7-14 hari setelah tubuh terinfeksi. Jumlah antibodi akan meningkat seiring dengan waktu hingga mencapai jumlah maksimum dan akan tetap dipertahankan keberadaannya dalam darah hingga beberapa waktu lamanya.

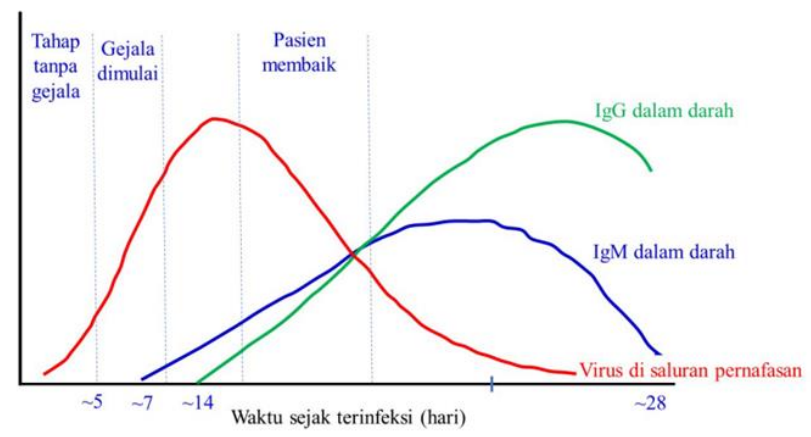

Gambar 3. Dinamika SARS Cov-2 dalam tubuh orang yang terinfeksi sampai pembentukan kekebalan tubuh

Sumber : (Wahjudi, 2020)

Keberadaan asam nukleat virus dalam tubuh terdeteksi sekitar 4-7 hari setelah infeksi tetapi tidak terdeteksi di awal dan akhir fase infeksi. Sedangkan antibodi mulai terdeteksi 7 hari setelah infeksi. Hasil uji swab negatif belum tentu menunjukkan tidak ada infeksi COVID-19. Kemungkinan yang terjadi pada hasil uji swab negatif adalah individu tidak terinfeksi coronavirus atau terinfeksi tetapi sampling dilakukan tidak pada fase infeksi yang tepat. Sedangkan rapid test antibodi negatif dapat menunjukkan kemungkinan individu tidak terinfeksi atau terinfeksi tetapi antibodi belum bahkan tidak terbentuk. Berdasarkan dinamika virus dalam tubuh orang terinfeksi dan dinamika pembentukan antibodinya maka hasil rapid test antibodi bisa sama dan bisa juga tidak sama dengan hasil uji molekuler sampel swab. Pada pasien dengan gejala COVID-19 maka penegakan status pasien COVID-19 lebih jelas, sedangkan pada kasus orang tanpa gejala maka diperlukan pengujian kedua untuk konfirmasi terutama pada pasien dengan latar belakang dan situasi khusus. (Walls, 2020)

\section{Uji Molekular/ Reverse Transcription-Polimerase Chain Reaction}

Uji molekuler secara RT-PCR dilakukan dengan metoda nucleic acid amplification tests sesuai rekomendasi oleh WHO. Bila diperlukan, konfirmasi dilanjutkan dengan sekuensing asam amino. Uji molekuler ini juga dikenal sebagai uji diagnostik, dan uji viral. Sampel untuk uji RT-PCR diambil dari sampel saluran pernapasan atas dan bawah nasofaring. Beberapa kit komersial diambil dari saliva (air liur). Pelaksanaan metode ini, seluruhnya harus dilakukan dalam suatu biosafety cabinet dengan fasilitas di laboratorium level 2. Selain itu pelaksanaan uji memerlukan tenaga terlatih. RT-PCR mendeteksi keberadaan RNA genom virus (SARS-CoV-2) dari lingkungan atau permukaan suatu benda, atau dari suatu sampel klinis (seperti sputum). Uji didasarkan pada keberadaan urutan spesifik dan unik dari RNA virus. Sebelum proses PCR dilakukan, RNA genom virus diekstraksi terlebih dahulu. RNA virus kemudian diubah menjadi complementary DNA (cDNA) 
karena pada reaksi PCR, hanya DNA yang dapat berfungsi sebagai cetakan. Dalam campuran reaksi PCR, salah satu komponen penting dalam campuran reaksi adalah probe, terdapat daerah tertentu pada genom virus diperbanyak sehingga jumlah potongan DNA ini cukup banyak untuk dideteksi dengan mudah. Perbanyakan hanya dapat terjadi bila seseorang terinfeksi oleh corona virus target. Daerah pada RNA virus yang umumnya menjadi target PCR adalah gen $\mathrm{N}, \mathrm{E}, \mathrm{S}$ dan RdRP. Metode PCR dari sampel swab saluran pernapasan atas akan memberikan hasil terpercaya hanya bila sampel diambil pada tahap awal infeksi. Kemudian seminggu setelah infeksi maka virus akan menghilang dari tenggorokan dan berkembang biak dalam paru-paru. Uji ini akan bermanfaat bila sampel berasal dari infeksi tahap awal, yaitu beberapa hari hingga 2 minggu setelah infeksi. Pada pasien akut, keberadaan virus di saluran pernafasan atas ini bisa lebih lama. Pada pasien yang terinfeksi lebih dari dua minggu, diperlukan pengambilan sampel dari saluran napas yang lebih dalam, dengan cara penyedotan dengan kateter (aspirasi) atau pengeluaran lewat batuk). Pelaksanaan uji RT-PCR memerlukan waktu antara beberapa jam hingga 2 hari, bahkan seminggu. Oleh karena itu, uji lebih bermanfaat untuk konfirmasi keberadaan infeksi dibandingkan menunjukkan hilangnya virus. Uji ini juga memungkinkan identifikasi dan isolasi orang terinfeksi dan dengan demikian dapat memutus mata rantai penyebaran.

Dibandingkan dengan DNA sequenching, metode RT-PCR lebih murah, lebih mudah dan tidak memakan waktu lama. Oleh karena itu, banyak lembaga dan perusahaan telah mengembangkan metode deteksi RT-PCR SARS CoV-2 yang telah memainkan peran kunci dalam mengendalikan SARS-CoV-2 menyebar lebih lanjut (Ai et al., 2020)

\section{Metode deteksi nukleotid komersial}

Banyak perusahaan dan lembaga diagnostik molekuler berusaha untuk mengembangkan perangkat molekuler titik perawatan yang terintegrasi, akses acak, untuk diagnosis infeksi SARS-CoV-2 yang lebih cepat dan akurat. Pada April 2020 Federasi Obat dan Makanan sudah menyetujui lebih dari 37 RNA SAR-Cov-2 deteksi kit. Perusahaan-perusahaan penyedia deteksi kit ini terus mengembangkan metode deteksi lebih akurat, diantaranya adalah Gnomegen yang mengembangkan RTd-PCR yaitu digital reverse transcription-PCR yang lebih sensitif membaca kadar virus yang rendah. Oleh karena itu, kit RT-PCR merupakan pilihan yang lebih baik untuk mendeteksi sampel dengan viral load rendah dan pendekatan ini akan secara signifikan meningkatkan kapasitas skrining CoVID-19

\section{Metode deteksi nukleotid non komersial}

Diantaranya adalah RT-Lamp Assay, yaitu Loop-mediated isothermal Amplification (LAMP) mungkin menjadi alternatif yang paling menjanjikan untuk PCR karena menawarkan beberapa keunggulan dalam hal spesifisitas, sensitivitas, efisiensi reaksi, dan hasil produk. 


\section{NP (Nukelokapside Protein) Antigen Detection Assay}

Uji ini mendeteksi protein spesifik virus. Protein virus yang dapat digunakan untuk mendeteksi SARSCoV pada umumnya adalah protein nukleokapsid. Nukleokapsid protein dapat dideteksi secara ELISA dalam spesimen aspirasi nasofaring dari hari ke 6 sampai dengan 24 hari; dalam spesimen urin dari hari ke 11 ke 31, dan dalam specimens fekal dari hari ke 8 ke 32 setelah sakit dimulai. Studi sebelumnya telah menunjukkan bahwa NP coronavirus adalah protein struktural yang diturunkan dari virus dan predominan yang dilepaskan dalam jumlah besar ke dalam serum, aspirasi nasofaring, sampel cuci tenggorokan, feses, dan urin selama periode awal infeksi (Das et al., 2010). Oleh karena itu, deteksi antigen NP mungkin menjadi cara yang efektif untuk skrining awal dugaan SARS-CoV (Woo et al., 2018). Lebih menarik lagi, antigen NP terdeteksi dalam urin $73,6 \%(14 / 19)$ pasien yang didiagnosis dengan COVID-19 (Diao et al., 2020)

\section{Antibody Detection Assay (Rapid Test Antibody)}

Deteksi antibodi cairan tubuh adalah strategi lain yang efektif untuk identifikasi infeksi virus corona. Sampai saat ini, dua antibodi darah tes telah dikembangkan untuk deteksi cepat SARS-CoV-2. Pertama metode mendeteksi antibodi serum, IgG/IgM, menargetkan RBD dari NP dari SARS-CoV-2. Uji ini memiliki spesifisitas 90,63\% dan sensitivitas 88,66\% (Wu \& Anderson, 2020) (Li et al., 2020).

Namun, urutan asam amina dari RBD SARS-CoV-2 memiliki $72 \%$ kesamaan dengan SARS-CoV (Chan dkk., 2020a); dengan demikian, beberapa antibodi yang menargetkan RBD dari SARS-CoV dapat mengikat RBD SARS-CoV-2 (Tian et al., 2020). Hasil antibodi anti-RBD positif palsu dapat diamati pada penelitian sebelumnya pasien SARS-CoV yang terinfeksi (Guo et al., 2020). Cai dkk. (2020) ditemukan bahwa satu peptida dari uji IgM antibodi berbasis $\mathrm{S}$ memiliki spesifisitas tinggi, $100 \%$, tetapi sensitivitas lebih rendah 71,4\%. Selain itu, jumlah deteksi antibodi dengan metodologi sandwich antigen ganda RBD adalah dilaporkan memiliki sensitivitas yang lebih tinggi daripada anti-RBD IgM atau IgG, terutama pada periode awal infeksi COVID-19. (Wyllie et al., 2020)

Serokonversi antibodi anti-RBD terjadi 11-14 hari setelah timbulnya morbiditas (Zhao et al., 2020). Serokonversi anti-NP IgM, pada beberapa pasien, terjadi 7-12 hari setelah onset morbiditas (Li et al., 2020) dan, pada beberapa pasien, satu hari setelah timbulnya gejala (Guo et al., 2020a,b); menunjukkan bahwa waktu serokonversi bervariasi antara orang-orang. Selain itu, beberapa pasien COVID-19 hanya memiliki satu serokonversi antibodi anti-SP atau anti-NP, menyiratkan bahwa ada respons imun yang berbeda terhadap NP dan RBD di antara orang-orang. Contoh waktu pengujian dan faktor imun penderita bisa berkontribusi pada hasil negatif palsu. (Levy et al., 2020), (Guo et al., 2020)

\section{Lateral Flow Assay}

LFA mudah digunakan, murah, dan mudah diproduksi secara massal. Banyak koloid emas koloid emas anti-SARS-CoV-2 antibodi LFA teladigunakan secara global dalam upaya untuk mengendalikan pandemi COVID-19. Selain itu, LFA mungkin merupakan metode optimal untuk deteksi di lapangan antigen SARS-CoV-2 dan 
RNA. Namun sensitivitas deteksi LFA terlalu rendah untuk mencapai skrining COVID-19 yang sangat akurat. Yang menggembirakan, sensitivitas deteksi LFA telah ditingkatkan dengan penggunaan nanomaterial baru sebagai imunolabel seperti titik kuantum, nanopartikel konversi naik, dan nanopartikel magnetic (Huang et al., 2016). Di antara mereka, LFA yang menggunakan bahan nano fluoresensi ultra-terang dengan masa pakai fluoresensi yang lebih lama dapat secara signifika mengurangi kebisingan latar belakang dan meningkatkan sensitivitas deteksi LFA menggunakan teknik analisis yang diselesaikan dengan waktu (C. Hu et al., 2017; L. M. Hu et al., 2017).

\section{Biosensor elektrokimia}

Jenis biosensor lain yang sangat menjanjikan untuk deteksi titik perawatan yang sangat sensitif terhadap SARS-CoV-2 adalah biosensor elektrokimia. Biosensor elektrokimia telah banyak digunakan untuk mendeteksi asam nukleat, protein, antibodi molekul kecil, dan virus. Uji ini cukup akurat dan hemat biaya untuk deteksi sensitivitas tinggi yang cepat (Dai dan Liu, 2019). Dalam sensor elektrokimia (EIS), targetnya adalah dikenali menggunakan reaksi antigen-antibodi, DNA, RNA, atau peptide hibridisasi asam nukleat (PNA) atau pengikatan berbasis aptamers masing-masing yang memiliki selektivitas dan sensitivitas tinggi untuk target deteksi (Labib dkk., 2016).

\section{Simpulan}

Screening dan deteksi penderita Covid-19 sangat perlu dilakukan dengan tepat dan cepat untuk pencegahan penyebaran virus Covid. Berbagai penelitian tentang cara pengujian, maupun penyediaan detection kit yang murah dan gampang di akses terus menerus dilakukan. Untuk screening, bisa dilakukan pengujian nukleocapside protein (uji antigen) dan pengujian darah (antibodi). Untuk test konfirmasi, dilakukan dengan PCR atau RT-PCR. Jika diperlukan pembuktian lebih lanjut, bisa dilakukan dengan sequencing asam amino.

Seiring dengan perkembangan hasil penelitian selama hampir dua tahun ini (2020-20210, ditemukan bahwa untuk screening, test antigen merupakan uji yang tepat. Hal ini dikarenakan uji ini bisa dilakukan dengan cepat, murah, dan dengan tingkat ketepatan yang tinggi. Saat ini uji antigen yang dilakukan sebagian besar adalah uji swap nasofaring (jaringan hidung).

Pengujian dengan antibody darah dinilai kurang tepat, karena bisa menghasilkan hasil negatif palsu. Hal ini karena adanya periode/ masa terbentuknya antibody dalam tubuh penderita. Uji antigen juga bisa menghasilkan negative palsu, jika beban virus (virus load) masih rendah. Untuk itu diperlukan pengujian lebih lanjut berupa test konfirmasi, yaitu RT-PCR. Untuk pencegahan penularan lebih lanjut, diperlukan kesadaran masyarakat untuk melakukan protokol kesehatan, seperti memakai masker, mencuci tangan, menjaga jarak. 


\section{Daftar Pustaka}

Ai, T., Yang, Z., Hou, H., Zhan, C., Chen, C., Lv, W., Tao, Q., Sun, Z., \& Xia, L. (2020). Correlation of Chest CT and RT-PCR Testing for Coronavirus Disease 2019 (COVID-19) in China: A Report of 1014 Cases. Radiology, 296(2), E32-E40. https://doi.org/10.1148/radiol.2020200642

Diao, B., Wang, C., Tan, Y., Chen, X., Liu, Y., Ning, L., Chen, L., Li, M., Liu, Y., Wang, G., Yuan, Z., Feng, Z., Zhang, Y., Wu, Y., \& Chen, Y. (2020). Reduction and Functional Exhaustion of T Cells in Patients With Coronavirus Disease 2019 (COVID-19). Frontiers in Immunology, 11(May), 1-7. https://doi.org/10.3389/fimmu.2020.00827

Hellewell, J., Abbott, S., Gimma, A., Bosse, N. I., Jarvis, C. I., Russell, T. W., Munday, J. D., Kucharski, A. J., Edmunds, W. J., Sun, F., Flasche, S., Quilty, B. J., Davies, N., Liu, Y., Clifford, S., Klepac, P., Jit, M., Diamond, C., Gibbs, H., ... Eggo, R. M. (2020). Feasibility of controlling COVID-19 outbreaks by isolation of cases and contacts. The Lancet Global Health, 8(4), e488-e496. https://doi.org/10.1016/S2214-109X(20)30074-7

Ji, T., Liu, Z., Wang, G., Guo, X., \& Akbar, S. (2020). Since January 2020 Elsevier has created a COVID-19 resource centre with free information in English and Mandarin on the novel coronavirus COVID-19. The COVID-19 resource centre is hosted on Elsevier Connect, the company's public news and information. January.

Ji, Y., Ma, Z., Peppelenbosch, M. P., \& Pan, Q. (2020a). Potential association between COVID-19 mortality and health-care resource availability. The Lancet Global Health, 8(4), e480. https://doi.org/10.1016/S2214-109X(20)30068-1

Kucharski, A. J., Russell, T. W., Diamond, C., Liu, Y., Edmunds, J., Funk, S., Eggo, R. M., Sun, F., Jit, M., Munday, J. D., Davies, N., Gimma, A., van Zandvoort, K., Gibbs, H., Hellewell, J., Jarvis, C. I., Clifford, S., Quilty, B. J., Bosse, N. I., ... Flasche, S. (2020). Early dynamics of transmission and control of COVID-19: a mathematical modelling study. The Lancet Infectious Diseases, 20(5), 553-558.

Levy, M., Chen, Y., Clarke, R., Bennett, D., Tan, Y., Guo, Y., Bian, Z., Lv, J., Yu, C., Li, L., Yip, W., Chen, Z., \& Mihaylova, B. (2020). Socioeconomic differences in health-care use and outcomes for stroke and ischaemic heart disease in China during 2009-16: a prospective cohort study of 0.5 million adults. The Lancet Global Health, 8(4), e591-e602. https://doi.org/10.1016/S2214-109X(20)30078-4

Li, R., Pei, S., Chen, B., Song, Y., Zhang, T., Yang, W., \& Shaman, J. (2020). Substantial undocumented infection facilitates the rapid dissemination of novel coronavirus (SARS-CoV-2). Science, 368(6490), 489-493. https://doi.org/10.1126/science.abb3221

Wahjudi, M. (2020). Kontroversi Metode Deteksi COVID-19 di Indonesia. KELUWIH: Jurnal Kesehatan Dan Kedokteran, 2(1), 32-42. https://doi.org/10.24123/kesdok.v2i1.2994

Walls, A. C. (2020). Walls, SARS Cov 2 glikoprotein.pdf.

$\mathrm{Wu}$, S., \& Anderson, C. S. (2020). A need to re-focus efforts to improve long-term prognosis after stroke in China. The Lancet Global Health, 8(4), e468-e469. https://doi.org/10.1016/S2214-109X(20)30086-3

Wyllie, A. L., Fournier, J., Casanovas-Massana, A., Campbell, M., Tokuyama, M., Vijayakumar, P., Geng, B., Muenker, M. C., Moore, A. J., Vogels, C. B. F., Petrone, M. E., Ott, I. M., Lu, P., Venkataraman, A., Lu-Culligan, A., Klein, J., Earnest, R., Simonov, M., Datta, R., ... Ko, A. I. (2020). Saliva is more sensitive for SARS-CoV-2 detection in COVID-19 patients than nasopharyngeal swabs. MedRxiv. https://doi.org/10.1101/2020.04.16.20067835 